\title{
СОЦІАЛЬНА ВІДПОВІДАЛЬНІСТЬ НА ЗАЛІЗНИЧНОМУ ТРАНСПОРТІ УКРАЇНИ: ЩОДО ОЦІНКИ НАСЛІДКІВ РЕФОРМУВАННЯ ТА МЕХАНІЗМУ ЗАБЕЗПЕЧЕННЯ
}

\author{
Компанієць В.В., д.е.н, професор (УкрДУЗТ)
}

\begin{abstract}
Охарактеризовано основні аспекти забезпечення соціальної відповідальності підприємств залізничного транспорту по відношенню до клієнтів $і$ персоналу в умовах реформування. Встановлено, щуо рівень соціальної відповідальності керівництва по віднотенню до працівників є низьким, що зумовлено як об'єктивними соціальноекономічними, так і людськими (духовно-моральними) чинниками і передбачає їх системні зміни.
\end{abstract}

Ключові слова: підприсмства залізничного транспорту, реформування, соціальна відповідальність, соціально-економічні, духовно-моральні чинники, заробітна плата, колективний договір.

\section{СОЦИАЛЬНАЯ ОТВЕТСТВЕННОСТЬ НА ЖЕЛЕЗНОДОРОЖНОМ ТРАНСПОРТЕ УКРАИНЫ: ОТНОСИТЕЛЬНО ОЦЕНКИ ПОСЛЕДСТВИЙ РЕФОРМИРОВАНИЯ И МЕХАНИЗМА ОБЕСПЕЧЕНИЯ}

\author{
Компаниец В.В., о.э.н, профессор (УкрГУЖТ)
}

\begin{abstract}
Охарактеризовань основные аспекть обеспечения сочиильной ответственности предприятий железнодорожного транспорта по отношению к клиентам и персоналу в условиях реформирования. Установлено, что уровень социальной ответственности руководства по отночению к работникам является низким, что обусловлено как объективными сочиильно-экономическими, так и человеческими (духовно-нравственными) факторами и предполагает их системное изменение.
\end{abstract}

Ключевые слова: предприятия жселезнодорожсного транспорта, реформирование, социальная ответственность, социально-экономические, духовнонравственные факторы, заработная плата, коллективный договор.

\section{SOCIAL RESPONSIBILITY TO \\ RAILWAY TRANSPORT OF UKRAINE: REGARDING ASSESSMENT IMPACT OF THE REFORM AND MECHANISM}

\author{
Kompaniets V. V., Doctor of Economics, Professor \\ (Ukrainian State University of Railway Transport)
}

The article describes the main aspects of the social responsibility of enterprises of railway transport in relation to clients and staff in the conditions of reforming. Systemic changes in the economy and in the industry have a negative impact on the state of social responsibility on the railways. This shortfall manifests itself in state taxes, reducing the

() Компанієць В.В.

Вісник економіки транспорту і промисловості № 55, 2016 
quality of customer service (security, price, comfort), the deterioration of social support to workers in the industry and satisfactory quality of their working lives, needs satisfaction. In the future, the situation may worsen as the basic document regulating social obligations between workers and the company - a collective agreement, a draft of which is represented by the management of JSC "Ukrainian Railways", contrary to the principles of social responsibility.

Provision of social responsibility of enterprises of railway transport should be based on socio-economic and spiritual-moral principles. The first component provides the financial basis for socially responsible activities. Its development - the control function on the level of the state and industry. The second component provides the human, cultural basis of socially responsible activities. Its development - function change of consciousness of managers and employees through vnutilichnostnuyu work and training.

Keywords: enterprises of railway transport, reform, social responsibility, socioeconomic, spiritual and moral factors, wages, collective bargaining agreement.

\section{Постановка}

Актуальність. Огляд публікацій. Для забезпечення розвитку економіки та суспільства діяльність будь-яких підприємств повинна регулюватися як правовими, так і моральними важелями. Це обумовлює формування такого інституту як соціальна відповідальність бізнесу (підприємства, підприємця).

Західні компанії, у тому числі підприємства залізничного транспорту, розуміють важливість забезпечення соціально-відповідальної діяльності. Що стосується українських залізниць, то в минулому залізничний транспорт проводив активну соціальну політику по відношенню до працівників та клієнтів. Зараз сочіальна складова для підприємств залізнииі $\epsilon$ далеко не на першому місиі $i$ це знижує мотивацію та якість праці, негативно впливає на якість послуг залізничного транспорту. Але цей факт усвідомлюється через відчуття складних реалій життя працівниками залізничного транспорту, а не через аналітичні докази, оскільки публікацій, які б були присвячені дослідженню зміни стану соціальної відповідальності під впливом реформ (як в економіці у иілому, так $і$ на транспорті), майже немає.

Взагалі, дослідженню аспектів соціальної відповідальності на залізничному транспорті присвячено публікації науковців та фахівців $\begin{array}{llr}\text { залізничного } & \text { транспорту, } \\ \text { С.Андрощук, } & \text { О.Буряк, } & \text { О.Ворома }\end{array}$ В.Польової, І. Токмакової, Л. Шевченко.

Mema cmammi. Але гострота проблеми вимагає подальшого поглибленого вивчення стану соціальної відповідальності на підприємствах залізничного транспорту в умовах системних змін. I особливо це стосується кадрової складової. Розкриття цих положень і буде метою статті.

Основний матеріал. Корпоративна соціальна відповідальність українських залізниць - це добровільний внесок компанії у розвиток держави, суспільства, бізнесу в економічній, соціальній, екологічній сферах, який безпосередньо пов'язаний із господарською діяльністю усіх підприємств залізничного транспорту [1, c. 175].

Забезпечення соиіальної відповідальності (далі СВ) базується на двох основних складових: сочіальноекономічній та духовно-моральній. Перша пов'язана із наявністю доходів та прибутку (відповідно обсягу перевезень). Друга- 3 особистісними рисами i поведінкою керівників, станом культури організації.

На жаль, упродовж 2012-2015 pp. на залізничному транспорті (далі 3Т) спостерігається тенденція зниження обсягів перевезень, відповідно доходів та прибутку, а з 2014 р. його діяльність стає збитковою (таблиця 1). 
Таблиия 1

Основні обсягові та фінансові показники роботи Укрзалізнищі за 2010-2015 рр. [розраховано за 2-4]

\begin{tabular}{|c|c|c|c|c|c|c|}
\hline Показник & 2010 & 2011 & 2012 & 2013 & 2014 & 2015 \\
\hline Приведена продукція, млн ткм & 293163,8 & 327159,0 & 327905,5 & 308610,8 & 284350,9 & $232480,5 *$ \\
\hline Дохід від реалізації, млн грн & 42557,2 & 51586,5 & 52725,3 & 51049,8 & 49455,6 & 60125,6 \\
\hline у т.ч. вантажні перевезення & 32411,4 & 39810,9 & 40956,1 & 38805,4 & 39308,8 & 49099,2 \\
\hline $\begin{array}{c}\text { Чистий прибуток (збиток), млн } \\
\text { грн }\end{array}$ & 6688,0 & 2127,2 & 885,5 & 545,3 & $\begin{array}{c}15407, \\
0\end{array}$ & $\begin{array}{c}\text { - } \\
16789,6 * *\end{array}$ \\
\hline Рентабельність, \% & 15,7 & 4,1 & 1,7 & 1,1 & $-31,2$ & $-27,9$ \\
\hline
\end{tabular}

*за попередніми даними

** без урахування дооцінювання вартості основних фондів

Усі ці процеси системно впливають на стан усіх складових СВ.

Так, зниження СВ залізничного транспорту по відношенню до держави зокрема проявляється у тому, що внаслідок зменшення прибутків 3Т, його збитковості, держава недоотримує податки.

Мізерне фінансування оновлення основних фондів упродовж тривалого періоду призвело до вкрай високого ступеня їх зносу. А за останні два роки, за оцінкою аналітиків, усі фінансові потоки ЗТ спрямовані лише на забезпечення його поточної діяльності. Фізичний знос рухомого складу 3 т на кінець 2015 р. становив більше $90 \%$, у т.ч.: знос вантажних вагонів - 91,0\%, пасажирських - 86,0 \%, локомотивів - 95,7\% [5]. Зношеність основних фондів - це фактор безпеки руху та якості перевезень, який знижуе рівень СВ по віднотенню до усіх клієнтів залізниці (y т.ч. державних підприємств).

До факторів, які знижують рівень CB по відношенню до клієнтів 3T, відноситься i підвищення тарифів на пасажирські перевезення, яке не відповідає зростанню доходів населення, так у 2015 p. тарифи на пасажирські перевезення підвищились на 20-21\%, при цьому грошові доходи домогосподарств зросли лише на 12,4\%, а середньомісячний наявний дохід на душу населення - на $16,1 \%$ [6]. Особливо актуальною стає ця проблематика в контексті підвищення тарифів на комунальні послуги в 2016 р., скорочення робочих місць та інфляції. Внаслідок таких процесів для багатьох жителів Украӥни подорожування $3 T$ може стати і ризикованим (безпека руху), і таким, що набуває привілеїв (вартість).

Найбільш значущою i водночас найменш вирішеною проблемою $\mathrm{CB}$ підприємств є їх відповідальність перед свойм персоналом. До цілей цього рівня CВ відносяться: підтримка високої зайнятості працівників; зростання рівня та стимулюючої сили заробітної плати; покращення умов та безпеки праці; медичне обслуговування персоналу; професійне зростання кадрів; покращення житлових умов працівників; соціальне партнерство; розвиток системи корпоративної етики, захисту інтелектуальної власності, інформаційна безпека; встановлення пріоритету особистості як основної суспільної цінності, що визначає успіх діяльності підприємства [7, с.8].

Розглянемо рівень заробітної плати робітників ЗТ, як один 3 елементів соціальної відповідальності перед персоналом.

Так, за стандартами ООН, щоб праця не викликала демотивацію, iï оплата повинна відповідати мінімум 3 \$ за годину, тобто у 2015 p. за місяць складати приблизно 13026 грн (за курсом на грудень 2015 р.). При изьому середньомісячна заробітна плата працівників основної діяльності 3 склала у 2015 р. 4622,2 грн, тобто $35,5 \%$ від мінімальної 
середньомісячної заробітної, за стандартами $\mathrm{OOH}$ [розраховано за 8]. $A$ ось заробітна плата кожного члена правління ПАТ «Украӥнська залізниия» складає близько 400 тис. грн на місяџьь без урахування премій та інших надбавок [9]. Така різниия, вважаємо, характеризує стан «морального чинника керівництва».

32009 р. Укрзалізниця не виконує норму Галузевої угоди щодо підвищення заробітної плати залізничників на рівень, не нижчий за темпи іiі зростання в галузях економіки України. Так, у 2010 р. зарплата залізничників зросла на $14,5 \%$, а в галузях економіки - на 17,5 \%, у 2011-му, відповідно, на 15,4 та $17,6 \%$, у 2012 - на 14,4 і 14,9\%, у 2013-му - на 5,7 і 7,9 \%, у 2014-му на 5,1 i 6,5\%. За 11 місяців 2015 р. темп зростання заробітної плати у галузях економіки становив 19,1 \%, а зарплата залізничників за цей період зросла лише на 9,1\% - найнижчий показник серед галузей економіки [9]. Це призвело до того, що в 2015 р. середньомісячна заробітна плата на ЗТ була нижчою, ніж у промисловості, на 3,5 $\%$, тоді як у 2003 р. вона була майже на $41 \%$ вищою за іiі рівень у промисловості. У 2016 p. ситуація дещо покращилась: 3 початку року до липня зарплата залізничників зросла майже на $11,8 \%$, але не досягла рівня промисловості на 0,7\% [розраховано за 8].

Але при оцінці рівня СВ мова повинна йти не тільки про оплату праці. Працівник у процесі праці повинен уповні задовольняти усі свої потреби від базових до духовних, соціальних. Тобто $C B$ пов'язана із такою категорією, як якість трудового життя (далі - ЯТЖ).

Для того, щоб з'ясувати рівень ЯТЖ, що склався на підприємствах 3Т, нами було проведено опитування. В ньому взяли участь працівники (фахівці та робітники) різних підприємств ЗТ у кількості 100 осіб (65\% жінок та 35\% чоловіків) у віці від 20 до 50 років.

Щоб оцінити рівень ЯТЖ, були обрані відповідні блоки оцінки (таблиця
2). Методика передбачувала бальну оцінку опитуваним відповідних параметрів за вказаними блоками за шкалою від 0 до 10 балів за кожним параметром, яких у кожен блок входило десять. За результатами опитування виводилася середня оцінка за параметрами, блоками та взагалі за всією анкетою. Рівень ЯТЖ оцінювався за допомогою відповідної шкали.

Опитування показало, що якість трудового життя на ЗТ знаходиться на задовільному рівні (таблиця 2). Це викликає демотивацію праці, особливо у робітників, у яких рівень ЯТЖ нижче, ніж у фахівців. Це у свою чергу призводить до відчуття соціальної незахищеності, плинності кваліфікованих кадрів, негативно впливає на якість праці.

Більш за все фахівиі та робітники незадоволені рівнем заробітної плати та сочіальними благами (в параметри цього блоку входили, зокрема: оплата витрат на дитячі заклади, на спортивно-оздоровчі послуги, компенсація витрат на транспортування, харчування, надання пільгових кредитів на житло, відчуття соціального благополуччя), a також можливістю кар'єрного зростання. За блоком «Оплата праці» мінімальну оцінку отримали параметри «Можливість додаткової оплати» (оцінка 3,0 бала у фахівців та 3,1 бала у робітників), «Хороша заробітна плата» (3,2 бала у фахівців), «Відчуття економічного добробуту» (3,4 бала у робітників); максимальну оцінку параметр «Премія за вислугу років» (7,6 та 6,1 бала у фахівців та робітників, відповідно). За блоком «Службова кар'єра» мінімальний бал, як за оцінкою фахівців, так і працівників, отримав параметр «Бажання тривалої роботи» (5,0 балів). Блок «Соціальні блага»: мінімальний бал (4,5 для фахівців та 1,7 для робітників) отримав параметр «Оплата витрат на дитячі заклади». 
Таблиия 2

Рівень якості трудового життя фахівців та працівників підприємств залізничного транспорту

\begin{tabular}{|l|c|c|c|c|}
\hline \multirow{2}{*}{\multicolumn{1}{|c|}{ Показник }} & \multicolumn{4}{|c|}{ Рівень якості трудового життя } \\
\cline { 2 - 5 } & \multicolumn{3}{|c|}{ фахівці } & \multicolumn{2}{c|}{ робітники } \\
\cline { 2 - 5 } & значення & інтерпретація & значення & інтерпретація \\
\hline Трудовий колектив & 54 & задовільно & 53 & задовільно \\
\hline Оплата праці & 45 & незадовільно & 42 & незадовільно \\
\hline Робоче місце & 67 & задовільно & 52 & задовільно \\
\hline Керівництво організацією & 65 & задовільно & 58 & задовільно \\
\hline Службова кар'єра & 49 & незадовільно & 47 & незадовільно \\
\hline Соціальні гарантії & 79 & добре & 62 & задовільно \\
\hline Соціальні блага & 60 & задовільно & 37 & незадовільно \\
\hline Загальна оцінка & 417 & задовільно & 351 & задовільно \\
\hline
\end{tabular}

Але слід звернути увагу на те, щзо крім суто фінансових складових низьку оцінку отримали $i$ параметри, які забезпечуються дією людського чинника, $a$ саме поведінкою керівників - блоки «Трудовий колектив» та «Керівництво організацією», у т.ч. такі параметри, як «Довіра до керівників», «Задоволеність стилем керівництва», «Позитивна мотивація до праці», а найнижчу оцінку отримав параметр «Можливість виборності керівників» $(3,8$ бала у фахівців та 3,6 бала у робітників).

Те, щуо керівники демотивують прачівників, було встановлено $i$ у наших попередніх дослідженнях. Так, був задовільним рівень задоволеності прачівників роботою безпосереднього керівника [1. с. 242]. Вплив особистісного чинника керівника знижував мотивацію трудової поведінки, щчо проявлялось в несприянні творчому розвитку прачівників, прояву ініціативи, кар'єрному зростанню, відсутності поваги до думки підлеглих в процесі прийняття рімень, не завжжди справедливій та об'єктивній очінці їх праці, бездіяльності у вирішенні колективних і індивідуальних проблем і питань [10, с.109].

Про рівень ЯТЖ та СВ також свідчить рівень задоволеності потреб прачівників 3T, який ми визначили. При цьому було виділено базові потреби першого та другого рівнів, соціальнопсихологічні та творчі потреби.

Базові потреби першого рівня потреби, які пов'язані з оплатою праці та iii умовами, що відповідають базовим соціальним гарантіям. Розмір грошових коштів, які виділяються на ці потреби, залежить від розміру доходів 3Т. Базові потреби другого рівня - потреби, які пов'язані 3 турботою підприємства про робітника (матеріальна допомога у разі необхідності, безкоштовне харчування, безкоштовний проїзд, безкоштовне санаторно-курортне лікування, пільгові кредити та ін.) та можливістю користуватися об'єктами соціальної сфери (дитячі садки, медичні заклади, культурно-дозвільні установи, спортивні споруди та ін.). Розмір коштів, які виділяються на ці потреби, формується за рахунок чистого прибутку підприємств 3Т. Забезпечення иих базових потреб має фінансову основу.

Задоволення творчих та сочіальнопсихологічних потреб працівників має в основному немонетарну основу $i$ багато у чому залежить від дії особистісного чинника керівника. 
Опитування показали, що рівень задоволеності потреб у фахівців дещо більший, ніж у робітників, але взагалі знаходиться на задовільному рівні (таблиця 3).

Ми бачимо, що у більшій мірі незадоволені базові потреби другого рівня, що підтверджує задовільний стан соціальної політики $i$ є монетарним фактором. Але значна частка фахівців $(38,9 \%)$ та більшість робітників $(57,1 \%)$ незадоволені реалізацією соціальнопсихологічних потреб і майже половина робітників $(42,8 \%)$ - творчих. Це ще раз підкреслюе негативний вплив людського чинника (дії керівників).

Таблиия 3

Рівень задоволеності потреб фахівиів та робітників підприємств залізничного транспорту, \%

\begin{tabular}{|c|c|c|c|c|c|c|c|c|}
\hline \multirow{3}{*}{$\begin{array}{c}\text { Рівень } \\
\text { задоволенос } \\
\text { ті }\end{array}$} & \multicolumn{8}{|c|}{$\begin{array}{l}\text { Відсоток опитаних, які обрали відповідний рівень задоволеності } \\
\text { потреб }\end{array}$} \\
\hline & $\begin{array}{c}\text { базові } \\
\text { першог } \\
\text { о рівня }\end{array}$ & $\begin{array}{c}\text { базові } \\
\text { другог } \\
\text { о } \\
\text { рівня }\end{array}$ & $\begin{array}{c}\text { соціальн } \\
\text { о-психо- } \\
\text { логічні }\end{array}$ & $\begin{array}{l}\text { творч } \\
\text { i }\end{array}$ & $\begin{array}{c}\text { базові } \\
\text { першого } \\
\text { рівня }\end{array}$ & $\begin{array}{l}\text { базові } \\
\text { другог } \\
\text { о рівня }\end{array}$ & $\begin{array}{c}\text { соціальн } \\
\text { о-психо- } \\
\text { логічні }\end{array}$ & творчі \\
\hline & \multicolumn{4}{|c|}{ фахівці } & \multicolumn{4}{|c|}{ робітники } \\
\hline $\begin{array}{c}\text { Задоволени } \\
\text { й }\end{array}$ & 43,4 & 25,0 & 16,7 & 55,0 & 18,6 & 7,1 & 16,7 & 21,4 \\
\hline $\begin{array}{c}\text { Скоріше } \\
\text { задоволений }\end{array}$ & 26,6 & 33,3 & 33,3 & 33,3 & 32,9 & 25,0 & 21,4 & 35,7 \\
\hline $\begin{array}{c}\text { Скоріше } \\
\text { незадоволен } \\
\text { ий } \\
\end{array}$ & 20,0 & 16,7 & 16,7 & 11,7 & 13,9 & 25,0 & 35,7 & 21,4 \\
\hline $\begin{array}{l}\text { Незадоволе } \\
\text { ний }\end{array}$ & 6,7 & 25,0 & 22,2 & - & 32,8 & 35,8 & 21,4 & 21,4 \\
\hline $\begin{array}{c}\text { Важко } \\
\text { відповісти }\end{array}$ & 3,3 & - & 11,1 & - & 1,6 & 7,2 & 4,7 & - \\
\hline
\end{tabular}

У 2011-2012 рр. ми також проводили дослідження рівня задоволеності потреб працівників ЗТ за більш поглибленою методикою [1, с. 242], але порівнюючи результати, можливо зазначити, що ситуація суттєво не змінилась: базові потреби працівників так і задовольняються на низькому рівні, а задоволеність реалізацією творчих i соціально-психологічних потреб знизилась.

Крім анкетного, нами також було проведено неформальне опитуванняінтерв'ю працівників ЗТ щодо впливу реформування на соціальну складову. $\mathrm{Ha}$ жаль, працівники відмітили лише негативні наслідки реформування. Опитувані відзначили скорочення, а у деяких випадках і скасування матеріальної допомоги, скорочення видачі путівок у санаторії та дитячі табори. Всі працівники мають медичну страховку, але, у разі необхідності, виплат можуть не отримувати. Тобто соиіальні гарантії, зазначені $y$ колективних договорах, $y$ реальності часто не виконуються $і$ ие не завжди пов'язано із нестачею коштів, а може бути проявом нечесної поведінки керівників. Порушення принципів СВ до працівників полягає i y тому, що працівники можуть працювати неповний робочий тиждень, відповідно вони отримують зменшену заробітну плату, але реально виконують той самий обсяг робіт, який виконували при повному робочому тижні.

Отже, на підприємствах 3 т спостерігається низький рівень СВ 
керівництва по відношенню до працівників. Це викликано як об'єктивними чинниками (зниженням обсягу перевезень, доходів, чистого прибутку 3Т), так $i$ людськими (безвідповідальною поведінкою керівників, розкраданням коштів, які виділяються на забезпечення сочіального розвитку колективу, наявністю в системі корупиї та клановості).

\section{Важливим}

документом

регулювання сочіальних зобов'язань між працівниками та підприємством $\epsilon$ колективний договір. Саме за допомогою його аналізу можливо охарактеризувати ставлення до працівників (людський чинник) з боку керівництва. Колективний договір ПАТ «Українська залізниця» ще не прийнятий. Існує два проекти договору: перший підготовлений керівництвом ПАТ «Українська залізниця», другий Спільним представницьким органом (далі - СПО) профорганізацій ПАТ «Українська залізниця». Проект керівництва у грудні 2015 р. було обговорено на розширеній відеоконференції за участі представників дорожніх, територіальних, об’єднаних i первинних профорганізацій. Учасники наради дійшли одностайного висновку: правління ПАТ «Українська залізниця» відійшло від раніше висловлених обіцянок щодо збереження соціальних гарантій залізничників. Адже презентований представниками Товариства проект колективного договору докорінно відрізнясться від проекту, розробленого СПО профорганізачій, чинної Галузевої угоди та колдоговорів залізницьь та підприємств $і$ значно скорочує більшість соичіальних пільг та гарантій працівників $i$ ветеранів залізничного транспорту [12].

Проаналізувавши два проекти колективних договорів, ми бачимо, що проект колективного договору який представлений керівництвом ПАТ «Українська залізниця» дійсно суперечить принципам соціальної відповідальності. $У$ таблииі 4 наведені основні відмінності двох проектів колективних договорів щзодо основних пільг та гарантій, заробітної плати та збереження штату працівників.

Таблиия 4

Порівняння пунктів проектів колективних договорів

\begin{tabular}{|c|c|}
\hline $\begin{array}{c}\text { Проект СПО профорганізацій } \\
\text { «Колективний договір ПАТ «Українська } \\
\text { залізниця» на 2016-2021 роки» }\end{array}$ & $\begin{array}{l}\text { Проект керівництва ПАТ «Українська } \\
\text { залізниця» «Колективний договір ПАТ } \\
\text { «Українська залізниця» на } 2016 \text { рік» }\end{array}$ \\
\hline 1 & 2 \\
\hline $\begin{array}{l}\text { Витрати, пов’язані з наданням пільг та } \\
\text { соціальних гарантій, передбачених } \\
\text { Договором, здійснюються за рахунок } \\
\text { коштів Товариства } \\
\end{array}$ & $\begin{array}{l}\text { Витрати, пов'язані з наданням гарантій та } \\
\text { компенсацій, передбачених Договором, } \\
\text { здійснюються за рахунок Товариства в межах } \\
\text { фінансової можливості }\end{array}$ \\
\hline $\begin{array}{l}\text { Здійснити підвищення тарифних } \\
\text { ставок (посадових окладів) не менше ніж } \\
\text { на } 50 \% \text { \% } 1.01 .2016 \text { р. }\end{array}$ & - \\
\hline $\begin{array}{l}\text { Підвищення заробітної } \\
\text { працівникам Товариства здійснювати } \\
\text { шляхом перегляду тарифних ставок } \\
\text { (посадових окладів) } \\
\text { міжрозрядних збереженням } \\
\text { співвідношень, але не рідше двохесійних } \\
\text { рік }\end{array}$ & \begin{tabular}{lllr}
\multicolumn{1}{c}{3} & метою & \multicolumn{3}{c}{ забезпечення } \\
конкурентоспроможності & заробітної плати \\
працівників & Товариства на ринку праці \\
підвищувати & їі реальний розмір nо мірі \\
зростання & продуктивності праці \\
ефективності діяльності Товариства &
\end{tabular} \\
\hline
\end{tabular}


Продовження табл.4

\begin{tabular}{l} 
1 \\
\hline Річний темп підвищення заробітної \\
плати працівників повинен бути не нижче \\
темпів зростання заробітної плати в \\
галузях економіки і забезпечувати \\
підвищення рівня заробітної плати \\
щороку не менше рівня інфляції на \\
споживчому ринку України \\
Встановити мінімальний розмір \\
заробітної плати за просту, \\
некваліфіковану працю у розмірі не \\
менше 130\% від мінімальної заробітної \\
плати, встановленої законодавством \\
\hline Визначити розмір тарифної ставки \\
робітника 1 розряду для робітників, \\
зайнятих на експлуатаційній роботі та \\
інших роботах, у розмірі не менше \\
$140 \%$ прожиткового мінімуму для \\
працездатних осіб, встановленого \\
законом
\end{tabular}

$\mathrm{He}$ допускати масових звільнень працівників. У випадку скорочення обсягів робіт зменшення чисельності працівників проводити, в першу чергу, шляхом природної плинності кадрів та тимчасового обмеження прийому на роботу
Звільнення працівників за скороченням чисельності або штату застосовувати лише як вимушений захід та вживати усіх необхідни заходів щзодо їх подальшого працевлаштування, в тому числі пропонувати працевлаштування на інші підрозділи Товариства, проходження перепідготовки за професіями, в яких $\epsilon$ потреба у Товаристві (його підрозділах), а також у виняткових випадках тимчасову та сезонну зайнятість
Годинна тарифна ставка першого розряду першого рівня Єдиної тарифної сітки для оплати праці робітників встановлюється нормативними документами ПАТ «Укрзалізниця» і $є$ мінімальним розміром оплати праці в ПАТ «Укрзалізниця» і не може бути нижче $20 \%$ від мінімальної заробітної плати, встановленої законодавством

Скорочення чисельності працівників у випадку зменшення обсягів робіт проводити відповідно до Кодексу законів про працю

Звільнення за скороченням чисельності або штату допускається, якщзо неможливо перевести працівника за його письмової згоди на іншу наявну в Товаристві роботу (як на вакантну посаду або роботу, відповідну кваліфікації працівника, так і на вакантну нижчу посаду або нижчеоплачувану роботу), яку працівник може виконувати 3 урахуванням стану його здоров'я. Товариство зобов'язане пропонувати прачівникові всі вакансії, що відповідають зазначеним вимогам, наявні у нього в адміністративнотериторіальних межах населеного пункту, де розташоване робоче місце працівника, у тому числі в підрозділах філій та інших структурних підрозділах Товариства, розташованих там же

Надавати переважне право на працевлаштування на вакантні посади працівникам, які вивільняються за скороченням чисельності або штату
Надавати переважне право на працевлаштування на вакантні посади працівникам, які вивільняються за скороченням штату, протягом року 
Отже, виходячи із цього порівняння ми бачимо, що дійсно планується зменшення витрат пов'язаних з виплатою пільг та соиіальних гарантій, тому що їх розмір залежить від фінансових можливостей залізниці, а можливості залізниці, як ми визначили раніше, зараз на дуже низькому рівні. Велика увага у проекті колективного договору профорганізацій приділяється заробітній платі та іiї підвищенню. Проект колективного договору керівництва залізниці не передбачає підвищення тарифних ставок і посадових окладів.

Хоча проект нового колективного договору містить пункти щзодо подальшого прачевлаштування вивільнюваних працівників, ці пункти розроблені недосконало та не мають спеціального механізму. Зазвичай це відбувається так: працівнику або кажуть, що вакантних місць немає, або переводять на менш оплачувану посаду та у подальшому працівник нібито «за власним бажанням» звільняється.

Як свідчить порівняння двох проектів колективного договору більшість гарантій ПАТ «Українська залізниця» пропонує зменшити або зовсім скасувати. При цьому кошти від зменшення гарантій не будуть направлені на збільшення заробітної плати залізничникам. Тож і виходить, що для працівників ця реформа полягає у скасуванні і зменшенні соціальних пільг і гарантій. Прийняття таких соціальних стандартів на галузевому рівні не дозволить працівникам 3Т мати конкурентний рівень оплати праці серед працівників галузей економіки України та забезпечити залізничникам гідну оплату за їхню сумлінну і відповідальну працю.

Отже, можна заключити, щуо у прочесі реформування постраждалою стороною може опинитися людина працівник підприємства чи споживач. Усе ие значно вплине на досить різке зниження рівня CB підприємств $3 T$.

Ми вважаємо, що для запобігання цьому на ЗТ повинен бути розроблений механізм забезпечення $C B$. Фундамент цього механізму повинен складатися із двох основ: духовно-моральної та соціально-економічної.

Для того, щуоб покращити ситуацію, необхідно принципово змінити nідхід до прочесу реформування, роблячи акиент на соиіальній складовій. Зрозуміло, що відновлення належного рівня доходності і прибутковості залізниць - це фактор, який пов'язаний із соціальноекономічною і політичною ситуацією в країні, реформами, які здійснюються. Керівники держави $i$ галузі нарешті повинні усвідомити, що 3 має стати стратегічним фактором розвитку нашої держави.

Але сочіальна відповідальність пов'язана не тільки з фінансовими факторами, а й з особистісними. Ї̈ стан визначається рівнем моральності $i$ культури усіх працівників підприємств 3 Т і особливо керівників.

Духовно-моральна основа - це, передусім, цінності керівництва, цінності персоналу, норми та кодекси, які у свою чергу утворюють організаційну культуру. Для того, щоб механізм забезпечення СВ ефективно працював, необхідно провести зміни цих параметрів шляхом проведення навчання керівників та працівників, виховання та навчання майбутніх працівників 3Т.

Необхідно впроваджувати кодекс соціальної відповідальності та етики діяльності підприємств 3Т. I найголовніше - необхідно, шобб самі керівники вищої та середньої ланок розуміли, щзо від їx поведінки, ставлення до працівників залежить морально-психологічний клімат в організації, ставлення працівника до праці - иі найголовнімі компоненти СB. Зміни на рівні керівництва передбачають, що воно: бажає та готове сприйняти модель соціально відповідального управління; здійснює реальні кроки щодо поступових внутрішніх змін у цінностях та мотивах, виходячи із цього поступово здійснює і зовнішні зміни в управлінні. 
Висновок. Отже, системні зміни в економіці і в галузі негативно вплинули на стан соціальної відповідальності на залізничному транспорті. Це проявляється у недоотриманні державою податків, зниженні якості обслуговування клієнтів (безпека, ціна, комфортність), у погіршенні соціальної підтримки працівників галузі та задовільному стані якості їх трудового життя, задоволеності потреб. I у перспективі ситуація може погіршитись, адже основний документ, що регулюе соиіальні зобов'язання між працівниками та підприємством колективний договір, проект якого представлений керівництвом ПАТ «Українська залізниця», суперечить принципам соціальної відповідальності.

Забезпечення

відповідальності

залізничного транспорту повинно базуватись на соціально-економічних та духовно-моральних засадах. Перша складова забезпечує фінансову основу соціальновідповідальної діяльності. ̈ї розвиток - функція управління на рівні держави та галузі, яка повинна сприяти підвищенню обсягу та якості перевезень, обслуговування, зменшенню витрат та підвищенню прибутку. Друга складова забезпечує людську, культурну основу соціальновідповідальної діяльності. ̈ї розвиток - функція зміни свідомості керівників та працівників через внутрішню працю та навчання.

\section{СПИСОК ЛІТЕРАТУРИ}

1. Компанієць, В. В. Управління розвитком соціально-економічних систем у духовно-моральному та соціокультурному вимірі. Частина 2. Якість управління соціальноекономічними системами: духовноморальні та культурні пріоритети (на прикладі залізничного транспорту) [Текст]: монографія / В. В. Компанієць. Х.: УкрДАЗТ, 2012. - 296 с.

2. Удосконалення реформування та розвитку залізничного транспорту в контексті реалізації структурних реформ в галузі. Аналітична записка [Електронний ресурс] - Режим доступу:

http://www.niss.gov.ua/articles/1662

3. Фінансові показники [Електронний ресурс] : інформація / - Режим доступу : https://www.uz.gov.ua/about/investors/financ ial_statements/

4.Довідник основних показників роботи залізниць України [Текст]: Державна адміністрація залізничного транспорту України. Київ, 2015.- 59 с.

5. Пояснювальна записка до консолідованого проекту фінансового плану ПАТ “Українська залізниця" на 2016 рік [Електронний ресурс] - Режим доступу : mtu.gov.ua〉files/ПЗ до ФП ПАТ УЗ на 2016 рік

6. Офіційний сайт державної служби статистики України [Електронний ресурс] - Режим доступу : http://www.ukrstat.gov.ua/

7. Ворона О.В. Формування системи соціально-господарської відповідальності підприємств залізничного транспорту України [Текст]: автореф. дис. ... канд.. екон. наук : 08.00.04 / Ворона Олена Василівна. - Х., 2010. - 24 с.

8. Середня заробітна плата [Електронний ресурс]: інформація / Профспілка залізничників і транспортних будівельників України. - Режим доступу : http://zalp.org.ua/

9. Уряд змінив в.о. голови правління Укрзалізниці [Електронний ресурс] Режим доступу: http://palm.newsru.ua/ukraine /30mar 2016/ zavgorodnyi_kravcov.html

10. Залізничникам - гідну оплату праці! [Електронний ресурс] : інформація / Профспілка залізничників і транспортних будівельників України. - Режим доступу : http://zalp.org.ua/

11. Компанісць В.В, Управління трудовою поведінкою працівників підприємств залізничного транспорту (соціокультурні домінанти): монографія [Текст] / В.В Компанієць, В.В. Польова. Х.: Видавництво «Лідер», 2016.-298 с 
12. Проект колективного договору з Профспілка залізничників і транспортних ПАТ «Українська залізниця» будівельників України. - Режим доступу : [Електронний ресурс]: інформація / http://zalp.org.ua/

Стаття надійшла: 11.10.16p.

УДК 331.2

\title{
УДОСКОНАЛЕННЯ СИСТЕМИ ОПЛАТИ ПРАЦІ НА ЗАЛІЗНИЧНОМУ ТРАНСПОРТІ УКРАЇНИ
}

\author{
Маслова В.О., к.е.н., доцент, \\ Лісна О.О., магістр (УкрДУЗТ)
}

У статті обгрунтовано удосконалення системи оплати пращуі на підприємствах та у виробничих підрозділах залізничного транспорту як найбільш дієвого мотиваційного методу впливу на підвищення результатів пращі в сучасних умовах господарювання. Визначено особливості організації оплати прачі на залізничному транспорті. Наголошено на необхідності підвищення мотиваџіï пращзі працівників, які впливають на якісні та кількісні показники роботи залізничного транспорту, у тому числі за рахунок впровадження елементів грейдингу.

Ключові слова: мотивація праці, система оплати праці, грейдинг, залізничний транспорт.

\section{УСОВЕРШЕНСТВОВАНИЕ СИСТЕМЫ ОПЛАТЫ ТРУДА НА ЖЕЛЕЗНОДОРОЖНОМ ТРАНСПОРТЕ УКРАИНЫ}

\author{
Маслова В.А., к.э.н., доцент, \\ Лесная О.А., магистр (УкрГУЖТ)
}

В статье обосновано усовершенствование системы оплаты труда на предприятиях и в производственных подразделениях железнодорожного транспорта как наиболее действенного мотивационного метода влияния на повышение результатов труда в современных условиях хозяйствования. Определены особенности организации оплаты труда на железнодорожном транспорте. Отмечена необходимость повышения мотиваџии труда работников, влияющих на качественные и количественные показатели работы железнодорожного транспорта, в том числе за счет внедрения элементов грейдинга.

Ключевые слова: мотивация труда, система оплаты труда, грейдинг, жселезнодорожный транспорт.

(C) Маслова B.O.,

Лісна О.O.

Вісник економіки транспорту і промисловості № 55, 2016 